\title{
EDITORIAL
}

\section{Imnografia creştină: de la contribuţii apusene la noi perspective şi deziderate}

\author{
Alexandru PRELIPCEAN*
}

Atunci când am acceptat cu (destul de) multă uşurinţă să fiu editorul acestui număr tematic, dilema existenţială care mă presa era „sudată" de interogaţia ce titlu să deţină acest fascicul? Aveam numeroase idei şi proiecte, dar parcă nimic nu se ţesea mai bine decât să regândesc un vechi plan pentru un număr tematic dedicat imnografiei creştine. De altfel, şi acum îmi amintesc de realitatea descrisă de către mitropolitul Simeon Koutsas, care, în prologul comentariului său la Canonul cel Mare, atrăgea atenţia cu privire la lipsa înţelegerii sensurilor absconditus din imnografia creştină: „,credem că imnele noastre nu sunt astăzi înţelese de către marea parte a comunităţii eclesiastice. Desigur, mulţi le urmează cu interes. Destui, poate, vor simţi şi frumuseţea lor spirituală, atunci când imnele sunt cântate în mod corect şi cu smerenie, ca de exemplu, imnele Săptămânii Patimilor ce sensibilizează, mai cu seamă, pe credincioşi. Nu credem, însă, că urmărirea lor de către

\footnotetext{
" Asistent universitar la Facultatea de Teologie Ortodoxă „Dumitru Stăniloae”, Universitatea „Alexandru Ioan Cuza” din Iaşi, România.
} 
cei mai mulţi este una conştientă, că esenţa lor devine inteligibilă şi că, într-adevăr, contribuie la comuniunea credincioşilor cu Dumnezeu. Desigur, pentru această neînţelegere nu sunt de vină imnele, care sunt creaţii inspirate ale poeţilor şi care constituie monumente luminoase ale cuvântului poetic religios, sfinţit înăuntrul prelungirii activităţii liturgice a Bisericii. Dificultatea înţelegerii stă în limbajul lor, care nu este accesibil credinciosului de astăzi şi, astfel, nu poate nici înţelesul lor să-1 cuprindă şi nici de frumuseţea lor duhovnicească să se folosească" ${ }^{1}$.

In extenso, problematica aceasta este dublată şi de realitatea că, în spaţiul ştiinţific românesc, nu există niciun manual de imnografie creştină ${ }^{2}$ (cum se regăseşte, de altfel, în alte medii, fie el apusean, fie elenic) $)^{3}$, cum nici valorificări serioase şi de substanţă.

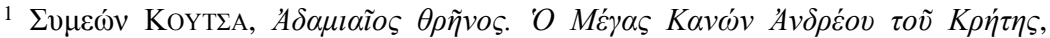

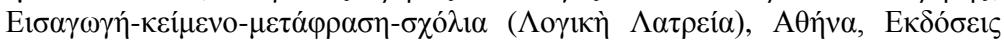

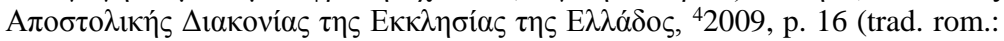
Simeon Koutsa, Mitropolit de Nea Smirna, Plânsul adamic. Canonul cel Mare al Sfântului Andrei Criteanul, Introducere-text-traducere-comentarii, trad. Alexandru Prelipcean, Iaşi, Doxologia, 2012, p. 10).

2 Singura excepţie ar putea fi considerată monografia lui Pr. Petre VINTILESCU, Despre poezia imnografică din cărţile de ritual şi cântarea bisericească, ClujNapoca, Renaşterea, ${ }^{2} 2005$.

${ }^{3}$ Vezi, spre exemplificare (în ordine cronologică), următoarele monografii: J.B. PITRA, Hymnographie de l'Eglise Grecque, Dissertation accompagnée des offices du XI Janvier, des XXIX et XXX Juin, en l'honneur de S. Pierre et des Apotres, Imprimerie de la Civiltà Cattolica, Rome, 1867; Edmond Bouvy, Poètes et Mélodes: études sur la origines du rythme tonique dans l'hymnographie de l'Eglise greque, Nimes, 1886; Henry Julius Wetenhall TILlyard, Byzantine music and hymnography, The Faith Press, 1923; Egon Wellesz, A History of Byzantine Music and hymnography, Oxford,

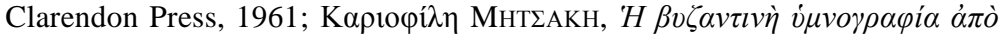

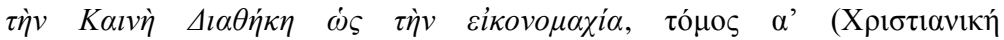

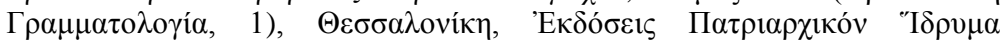

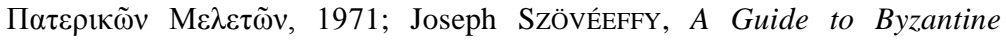

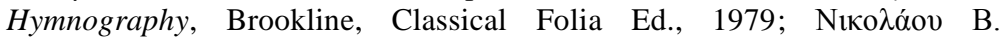

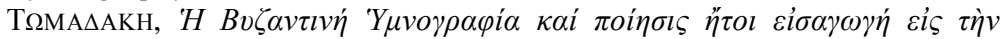

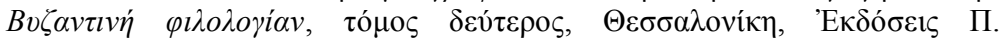

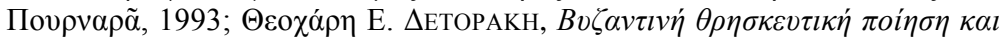

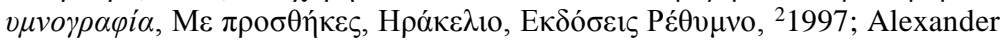
HAZHDAN, A History of Byzantine literature (650-850) in collaboration with 
Poate că traducerea în limba română a Dicţionarului de termeni liturgici şi imnologici al prof. C. Nikolakopoulos ${ }^{4}$, dublat de volumul editat de Al. Ioniţă ${ }^{5}$ asupra perspectivelor critice privind imnografia liturgică bizantină vor deveni punctul de cotitură spre o evaluare pertinentă din partea specialiştilor a ceea ce reprezintă ousia poeziei teologice bizantine. Sperăm că această realitate va contribui la depăşirea înţelegerii imnografiei ca o „,cenuşăreasă a teologiei ortodoxe" şi va spori în următorii ani la o expansiune a monografiilor, studiilor şi articolelor dedicate diferitelor aspecte imnografice.

Cert este că studiile privind imnografia creştină au nevoie astăzi de o nouă evaluare (chiar una critică) şi anume: de o înţelegere concretă a realităţii istorice şi teologice pe care o transpun; de o receptare critică cu privire la transmiterea imnelor în cursul istoriei; de o hermeneutică clară cu privire la raportul dintre text şi cântec; de o inventariere a imnelor teologice şi de cunoaştere în detaliu a modului în care imnografia reflectă atât contextul religios, cât şi cel social sau istoric. Pe de altă parte, spaţiul românesc credem că are nevoie astăzi chiar şi de un Manual de imnografie creştină, care ar putea îngloba nu numai perpectivele istorice şi teologice ale imnografiei, cât şi bio-bibliografia marilor imnografi ai Bisericii despre care cunoaştem încă atât de infime informaţii.

L.F. Sherry-Ch. Angelidi, The National Hellenic Research Foundation, Institute for Byzantine Research (Research Series, 2), Athens, 1999;

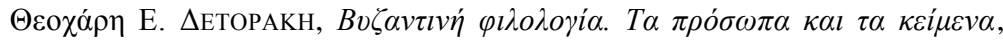

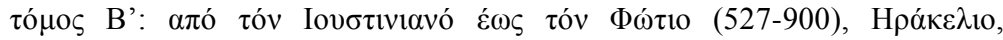

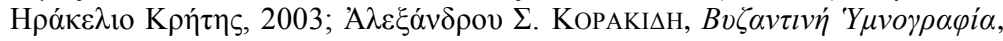

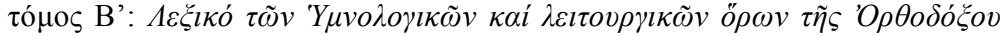

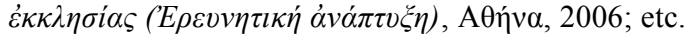

${ }^{4}$ Konstantinos NiKolaKopoulos, Imnografia ortodoxă la început şi astăzi. Dicţionar de termeni liturgici şi imnologici, trad. Alexandru Ioniţă, editată sub coordonarea ştiinţifică a prof. dr. Adrian Marinescu, Bucureşti, Basilica, 2015, 162p.

5 Alexandru Ioniţă (ed.), Imnografia liturgică bizantină. Perspective critice (Studia Oecoumenica, 13), Cluj-Napoca, Presa Universitară Clujeană, 2019, $347 \mathrm{p}$.

${ }^{6}$ Constantin OANCEA în „Cuvântul înainte” la volumul lui Alexandru IoniŢă (ed.), Imnografia liturgică bizantină..., p. 7 . 
Ceea ce am încercat în acest fascicul a fost tocmai să redăm pe cât a fost cu putinţă, desigur - noi opinii şi perspective cu privire atât la perioada bizantină, cât şi la spaţiul siriac cu privire la conţinutul imnelor creştine. De aceea, nădăjduim că volumul de faţă este un fascicul-invitaţie spre noi proiecte de cercetare, monografii şi studii cu aplecare spre imnografia creştină, pe care o răsfoim în cadrul cultului public, dar ale căror elemente secundare ne rămân încă (atât de) necunoscute.

Prezentul fascicul cuprinde un număr de şapte studii, redactate de specialişti din diferite domenii ale Teologiei (de la dogmatişti, patrologi, la cercetători şi oameni din domeniile Teologiei practice), alături de două recenzii din domenii diferite (ascetică şi imnografie). El acoperă, de altfel, perspectivele teologice şi practice ale imnografiei bizantine.

Astfel, primul studiu, semnat de cercetătoarea Eirini Artemi, este dedicat imnelor de la Utrenia sărbătorii Naşterii Domnului în Biserica Ortodoxă. Autoarea punctează realitatea că imnografia creştină este rodul teologiei dogmatice a Bisericii, iar în mod particular imnele care sunt dedicate Naşterii Domnului exprimă entuziasmul întregii creaţii la apariţia lui Dumnezeu pe pământ ca Om şi Dumnezeu desăvârşit.

Cunoaşterea planului întunecat şi cunoaşterea planului vieţii în cadrul dramaturgiei răului din condacul lui Roman Melodul, La răstignirea [Domnului] este cel de-al doilea studiu cuprins în fasciculul de faţă. Perspectiva teologică pe care prof. Ioannis Kourembeles o dezvoltă în acest studiu este, pe de o parte, de a-L prezenta pe Hristos prin puterea bunătăţiii Sale ca Binele suprem, iar pe de altă parte, să amintească ţesătura dialogală dramatică dintre Diavol şi Moarte în Săptămâna Pătimirilor cu intenţia lor declarată de a-L omorî pe Hristos. Studiul subsemnatului continuă perspectiva romaneică a imnografiei creştine, dar analizând aici opiniile cu privire la atitudinea antiiudaică a lui Roman Melodul în cadrul celor şase condace care au drept temă centrală Invierea 
Domnului. Pe lângă identificarea punctuală a unor (presupuse) intenţii antiiudaice a imnografului bizantin, studiul a căutat să descopere mai cu seamă valenţa hermeneutică teologică a celor şase condace pascale.

Continuând linia diacronică, Claudiu Ioan Coman propune un studiu incitant şi chiar surprinzător ca noutate: Imnografia, geometria și arhitectura bizantină. O hermeneutică teologică inedită, pe marginea unui tropar fotian. Ideea pe care o dezvoltă autorul este aceea că spaţiul eclesiastic are un rol important în gândirea teologică, împreună cu iconografia. Desigur, posibilitatea unei legături evidente între imnografia patriarhului Fotie şi arhitectură rămâne o problemă actuală, care va putea fi extinsă în cercetările ulterioare.

Studiul părintelui Roger Coresciuc are drept perspectivă centrală relaţia dintre Sfântul Grigorie Palama şi cântarea bisericească. Aşa cum accentuează autorul, omilii palamitice nu sunt doar predicile dogmatice sau cu caracter moral, ci conţin chiar şi referinţe despre cântarea bisericească. Dublate şi de unele elemente biografice, redactate de patriarhul Filotei, omiliile Sfântului Grigorie pot schiţa cadrul şi modul în care cântarea bisericească era apreciată în veacul al XIV-lea. În plus, studiul va evidenția și importanța pe care Sfântul Grigorie Palama o acordă legăturii dintre cântarea bisericii și rugăciunea minții, care este un element central al vieții isihaste.

Doctorandul Andrei Macar, ca viitor specialist în studiile siriace, propune lectorului un mini-manual de imnografie siriacă, sine qua non pentru înţelegerea contribuţiei acestui spaţiu la dezvoltarea imnografiei bizantine. Pornind de la originea acestei poezii de sorginte siriacă, de la timpul vieţuirii Sfântului Efrem Sirul şi de la mişcarea poetică pe care a generat-o, studiul va analiza forme ale poeziei metrice, dublate şi de portretizarea celor mai semnificativi poeţi din spaţiul siriac în Antichitatea târzie.

$\mathrm{Nu}$ în ultimul rând, studiul lui Gheorghe Mihalache mută perspectiva pastristică de până acum spre valenţe liturgice. Realitatea aceasta este demonstrată prin însuşi titlul propus: Sărbătoarea Schimbării la Faţă: de la imaginile biblice la istoria sărbătorii şi 


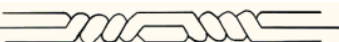

teologia ei imnografică. Studiul, foarte bine argumentat, este un peregrinatio prin imaginile narative ale Noului Testament cu referire la episodul Metamorphoses-ului, prin conturarea apariţiei istorice a sărbătorii şi, în final, prin analiza pertinentă a cuprinsului imnografic şi a temelor care reies din acesta.

Fasciculul se încheie cu secţiunea Recenzii, unde am introdus două lucrări. Prima, semnată de Daniel Lemeni, tratează modul în care lumea a perceput sfinţenia în Antichitatea târzie, iar cea de a doua recenzie (semnată de Claudiu Ioan Coman) analizează volumul de studii imnografice coordonat de Alexandru Ioniţă. 